\title{
HUBUNGAN ANTARA MOTIVASI KERJA DENGAN \\ KINERJA PERAWAT DI RSUD Mgr. GABRIEL MANEK SVD ATAMBUA
}

\author{
OLEH \\ CHINDY PRATIWI LALEL ${ }^{1)}$ \\ PIUS A. L. BEREK ${ }^{2)}$ \\ HANY TRIANA NAHAK ${ }^{3)}$
}

\begin{abstract}
1) 2) 3) Akademi Keperawatan Pemerintah Kabupaten Belu Jln. Wehor Kabuna Haliwen, Atambua Nusa Tenggara Timor. Post: 85711 Email: francis_domin2012@yahoo.com Telepon 081280426042
\end{abstract}

\begin{abstract}
ABSTRAK
Motivasi seseorang berawal dari kebutuhan, keinginan dan dorongan untuk bertindak demi tercapainya kebutuhan atau tujuan yang akan diwujudkan melalui kinerja. Penelitian ini bertujuan untuk menganalisa hubungan motivasi kerja dengan kinerja perawat di RSUD Mgr. Gabriel Manek, SVD Atambua. Penelitian ini menggunakan metode cross sectional dimana peneliti membagikan kuisioioner kepada perawat yang bersedia menjadi responden, setelah penelitian selesai, maka hubungan dengan responden juga berakhir disitu. Sampel dalam penelitian ini berjumlah 160 orang perawat. Data dikumpulkan dengan menggunakan kuesioner yang berisi daftar pertanyaan kepada para responden. Daftar pertanyaan meliputi motivasi kerja perawat dan kinerja perawat. Teknik analisis data menggunakan analisa descriptive statistics yang dioperasikan melalui program SPSS 22. Jenis data variabel independen dan dependen berupa data kategorik sehingga analisis selanjutnya peneliti menggunakan uji chi square. Hasil analisa dengan chi square nilai didapatkan $\mathrm{p}$ value adalah sebesar 0,000 artinya terdapat hubungan yang signifikan antara motivasi kerja dengan kinerja perawat di RSUD Mgr. Gabriel Manek, SVD Atambua. Disarankan perlu adanya penelitian yang lebih lanjut mengenai hubungan karakteristik individu dan motivasi kerja dengan kinerja perawat di RSUD Mgr. Gabriel Manek, SVD Atambua
\end{abstract}

Kata kunci : Motivasi kerja, kinerja perawat. 


\title{
RELATIONSHIP BETWEEN WORK MOTIVATION WITH NURSE PERFORMANCE IN GENERAL HOSPITAL OF Mgr. GABRIEL MANEK SVD ATAMBUA
}

\author{
By \\ CHINDY PRATIWI LALEL ${ }^{1)}$ \\ PIUS A. L. BEREK ${ }^{2)}$ \\ HANY TRIANA NAHAK ${ }^{3)}$ \\ 1) 2) 3) Nursing Academy of Belu Regency Jln. Wehor Kabuna Haliwen, Atambua \\ East Nusa Tenggara. Post: 85711 Email: francis_domin2012@yahoo.com Telepon \\ 081280426042
}

\begin{abstract}
Motivation begins with the need, desire and drive to act in order to achieve the needs or goals that will be realized through performance. This study aims to analyze the relationship between work motivation with nurse performance in General Hospital of Mgr Gabriel Manek, SVD Atambua. This study uses a cross sectional method where the researcher distributes questionnaires to nurses who are willing to become respondents, after the research is completed, the relationship with the respondents also ends there. The sample in this study amounted to 160 nurses. Data was collected using a questionnaire that lists questions to respondents. Questionnaires include nurse work motivation and nurse performance. Data analysis techniques used descriptive statistics analysis operated through the SPSS 22 program. The data types were independent and dependent variables in the form of categorical data so that the next analysis researchers used the chi square test. The results of the analysis with chi square values obtained $p$ value $=0,000$, it means that there is a significant relationship between work motivation and the performance of nurses in General Hospital of Mgr Gabriel Manek, SVD Atambua. It is recommended to have further research regarding the relationship of individual characteristics and work motivation with the performance of nurses in General Hospital of Mgr Gabriel Manek, SVD Atambua
\end{abstract}

Keywords: Work motivation, nurse performance.

\section{Latar Belakang}

Motivasi seorang berawal dari kebutuhan, keinginan dan dorongan untuk bertindak demi tercapainya kebutuhan atau tujuan. Hal ini menandakan seberapa kuat dorongan, usaha, intensitas, dan kesediaanya untuk berkorban demi tercapainya tujuan. Dalam hal ini semakin kuat dorongan atau motivasi dan semangat akan semakin tinggi kinerjanya. Di rumah sakit, sumber daya manusia terbanyak yang berinteraksi secara langsung dengan pasien adalah perawat, sehingga kualitas pelayanan yang dilaksanakan oleh perawat dapat dinilai sebagai salah satu indikator baik atau buruknya kualitas pelaya-nan di rumah sakit. Dalam pengelo-laan 
sumber daya manusia, hal penting yang diperhatikan adalah upayaupaya untuk memelihara hubungan yang kontinu dan serasi terhadap karyawan. Upaya tersebut berkenaan dengan kepuasan dan motivasi seorang perawat dalam bekerja. Kepuasan kerja (job satisfaction) merupakan wujud dari persepsi perawat yang tercermin dalam sikap dan terfokus pada perilaku terhadap pekerjaan. Juga merupakan suatu bentuk interaksi manusia dengan lingkungan pekerjaannya. Kepuasan kerja yang tinggi merupakan tanda bahwa organisasi telah melakukan manajemen perilaku yang efektif. Penelitian ini bertujuan untuk mengetahui hubungan antara motivasi kerja dengan kinerja perawat di RSUD Mgr. Gabriel Manek, SVD Atambua. Menurut (Gillies, 1996) isi pekerjaan merupakan faktor-faktor yang berhubungan dengan isi/content dari pekerjaan atau tugas, yang disebut sebagai motivating factors; bila hal ini dipenuhi akan menimbulkan kepuasan kerja (job satisfaction). Oleh karenanya dikatakan bahwa faktor yang memotivasi seseorang dalam melakukan suatu pekerjaan berada pada pekerjaan itu sendiri, dan apabila hal tersebut tidak dipenuhi akan menimbulkan ketidak puasan kerja (no job satisfaction).

Jumlah perawat di RUSD Mgr. Gabriel Manek, SVD Atambua sebanyak 592 orang perawat dan, Setiap tahunnya jumlah perawat bertambah. Menurut WHO tingkat motivasi kerja seorang perawat berkisar $32 \%-62,9 \%$, dan kinerja perawat $28,9 \%$. Sedangkan tingkat motivasi kerja dan kinerja perawat di Indonesia sebesar 83,6\%. Di NTT khususnya Kabupaten Belu tahun 2013 tingkat motivasi kerja dan kinerja perawat sebesar $59 \%$ jauh dari standar yang telah ditentukant, hal ini di pengaruhi oleh gaji atau imbalan yang di dapat.

Motivating factors terdiri dari beberapa factor, faktor-faktor tersebut diantaranya yaitu: Wewenang atau otonomi, Pengakuan, Kesempatan Berkarir, Penghargaan, Beban Kerja. Lingkungan Pekerjaan merupakan faktor yang diperlukan untuk mempertahankan tingkat kepuasan secukupnya dalam diri karyawan. Faktor-faktor tersebut bisa menjadi sumber untuk mempertahankan tingkat kepuasan secukup- 
nya dalam diri karyawan. Faktorfaktor tersebut bisa menjadi sumber ketidakpuasan pada seseorang dan berkaitan erat dengan suasana lingkungan pekerjaan. Faktor-faktor tersebut diantaranya adalah: Kebijakkan Organisasi, Hubungan dengan Atasan, Hubungan dengan Rekan Kerja, Imbalan, Kualitas Atasan Langsung, Kondisi Tempat Kerja (Gillies, 1996).

Bila faktor-faktor tersebut diatas dipenuhi atau diperbaiki maka akan mengurangi atau menghilangkan ketidakpuasan kerja (no job dissatisfaction), tetapi tidak akan menimbulkan kepuasan karena memang bukan sumber kepuasan kerja. Sebaliknya apabila tidak dipenuhi atau tidak ada perbaikan kondisi, maka akan mengakibatkan terjadinya ketidakpuasan kerja (job dissatisfaction). Upaya yang dilakukan untuk memenuhi kepuasan kerja karyaan atau tenaga kerja, harus diberikan penghargaan.

Penelitian ini bertujuan untuk mengetahui hubungan antara motivasi kerja dengan kinerja perawat di RSUD Mgr. Gabriel Manek, SVD Atambua.

\section{Metodologi}

Desain penelitian yang digunakan dalam penelitian ini adalah penelitian analitik korelatsi dengan pendekatan cross sectional yang digunakan untuk menganalisis hubungan antara motivasi kerja dan kinerja perawat di RSUD Mgr. Gabriel Manek, SVD Atambua. Jumlah sampel dalam peneni adalah 160 orang responden yang dipilih dengan menggunakan kuota sampling, dimana peneliti menyebarkan kuisioner kepada sejumlah besar sampel yang ditentukan. Setelah mencapai kuota tersebut, maka proses pengumpulan data dihentikan. Adapun kriteria inklusi dalam penelitian ini adalah 1) Bersedia menjadi responden; 2) Perawat pelaksana di Ruang Rawat Inap RSUD Mgr. Gabriel Manek, SVD Atambua; dan 3) Perawat pelaksana yang memiliki pendidikan minimal DIII, di Ruang Rawat Inap RSUD Mgr. Gabriel Manek, SVD Atambua. Berkaitan dengan etika penelitian, peneliti menjelaskan tujuan dan manfaat penelitian kepada responden, selanjutnya responden yang bersedia menjadi responden deiberi kesempatan untuk menandatangani 
lembar persetujuan menjadi responden. Dalam melaksanakan penelitian ini, peneliti mendapat ijin dari Kaprodi Keperawatan Unimor, Direktur RSUD Mgr. Gabriel Manek, SVD Atambua.

Pengumpulan data menggunakan kuesioner yaitu dengan memberikan daftar perta-nyaan atau kuesioner secara lang-sung kepada responden. Kuesioner tersebut merupakan angket tertutup yang terdiri dari dua bagian, yaitu bagian pertama yang terdiri atas pertanyaan-pertanyaan untuk mem-peroleh data pribadi responden dan bagian kedua yang digunakan untuk mendapatkan data tentang dimensi-dimensi dari konstruk-konstruk yang dikembangkan dalam penelitian ini. Pernyataanpernyataan dalam angket tertutup dibuat dengan menggunakan skala 15 untuk mendapatkan data yang bersifat dan diberi nilai atau skor, sebagai berikut: untuk dimensi motivasi kerja menggunakan skala bertingkat Likert sebagai berikut: 1: Sangat tidak setuju dengan pernyataan, 2: Tidak setuju , 3: Ragu ragu, 4: Setuju, 5: Sangat setuju . Sedangkan untuk kinerja, akan dikaitkan dengan skala bertingkat
Likert sebagai berikut : 1: Tidak pernah dilakukan, 2: Kadang kaddang di lakukan , 3: Sebagian dilakukan , 4: Sering dilakukan , 5: Selalu dilakukan. Alat pengumpul data-data penelitian ini diperoleh dari Nursalam (2013) yang berisi 35 pertanyaan yang terdiri dari 10 pertanyaan untuk motivasi kerja dan 25 pertanyaan untuk mengevaluasi kinerja perawat. Semua kuisoner ini telah dibakukan dan di uji validasi dan reliabel.

Data selanjutnya dilakukan analisa univariat dan bivariat. Analisa univariat bertujuan untuk mengiden-tifikasi prosentasi dari setiap variabel. Sedangkan analisis bivariat di-gunakan untuk menganalisa hubu-ngan antara 2 variabel, yaitu Hubu-ngan antara motivasi kerja dengan kinerja perawat. Dilakukan analisis risiko untuk menilai besar risiko setiap variabel terhadap hubungan antar motivasi dengan kinerja perawat di RSUD Mgr. Gabriel Manek, SVD Atambua. Uji hipotesis yang digunakan adalah uji chi square dengan kemaknaan $\mathrm{p}$ value < 0,05. Hasil penelitian ditampilkan dalam bentuk tabel dan diinterpretasikan secara naratif. 
Tabel 1

Distribusi Frekuensi Responden Berdasarkan Usia

di RSUD Mgr. Gbriel Manek, SVD Atambua, 21 Januari - 21 Februari 2015

$(\mathrm{N}: 160)$

\begin{tabular}{llcll}
\hline Variabel & $\begin{array}{l}\text { Mean } \\
\text { Median }\end{array}$ & Standar Devisiasi & $\begin{array}{l}\text { Minimal } \\
\text { Maximal }\end{array}$ & $95 \%$ CI \\
\hline USIA & 26,58 & 4,372 & 20 & $25,90-27,26$ \\
& 26,00 & & 56 &
\end{tabular}

Tabel 1 menunjukkan bahwa nilai rata - rata usia responden dalam penelitian ini adalah 26,58 tahun (95\% CI: 25,90- 27,26 ), dengan standar devisiasi 4,372. Usia termuda 20 tahun dan usia tertua 56 tahun. Dari hasil estimasi analisa data, 95\% diyakini bahwa rentang usia responden dalam penelitian ini adalah 25,90 27,26 tahun.

Tabel 2

Distribusi Frekuensi Responden Berdasarkan Lama Kerja di RSUD Mgr. Gbriel Manek, SVD Atambua, 21 Januari - 21 Februari 2015 (N: 160)

\begin{tabular}{lcccc}
\hline Variabel & $\begin{array}{c}\text { Mean } \\
\text { Median }\end{array}$ & Standar Devisiasi & $\begin{array}{l}\text { Minimal } \\
\text { Maximal }\end{array}$ & $95 \%$ CI \\
\hline Lama kerja & 4,39 & 4,602 & 1 & $3,67-5,11$ \\
& 3,00 & & 32 & \\
\hline
\end{tabular}

Tabel 2 menunjukkan bahwa rata - rata lama kerja responden dalam penelitian ini adalah 4,39 tahun (95\% CI:3,67-5,11), dengan standar devisiasi 4,602. Lama kerja tercepat 1 tahun dan lama kerja terlama 32 tahun. Dari hasil estimasi analisa data, 95\% diyakini bahwa rentang nilai lama kerja responden dalam penelitian ini adalah 3,67- 5,11 tahun. 
Tabel 3

Distribusi Frekuensi Responden Berdasarkan Jenis Kelamin di RSUD Mgr. Gabriel Manek, SVD Atambua, 21 Januari - 21 Februari 2015

$(\mathrm{N}: 160)$

\begin{tabular}{ccc}
\hline $\begin{array}{c}\text { Variabel } \\
\text { (Jenis Kelamin) }\end{array}$ & Frekuensi & Presentase \\
\hline $\mathrm{L}$ & 31 & $19,4 \%$ \\
$\mathrm{P}$ & 129 & $80,6 \%$ \\
\hline Total & 160 & $100 \%$ \\
\hline
\end{tabular}

Tabel 3 menunjukkan bahwa dari 160 responden, terdapat 129 orang responden yang berjenis kelamin perempuan dengan presentase $80,6 \%$, dan 31 orang responden lainnya berjenis kelamin laki- laki dengan presentase $19,4 \%$.

Tabel 4

Distribusi Frekuensi Responden Berdasarkan Tingkat Pendidikan, di RSUD Mgr. Gabriel Manek, SVD Atambua, 21Januari - 21Februari 2015 (N: 160)

\begin{tabular}{ccc}
\hline $\begin{array}{c}\text { Variabel } \\
\text { (Pendidikan) }\end{array}$ & Frekuensi & Presentase \\
\hline DIII & & $75,6 \%$ \\
S1 & 121 & $24,4 \%$ \\
\hline Total & 39 & $100 \%$ \\
\hline
\end{tabular}

Tabel 4 menunjukkan bahwa dari 160 responden, terdapat 121 orang responden tingkat pendidikannya adalah DIII Keperawatan dengan presentase 75,6\%, dan 39 orang responden lainnya adalah S1 Keperawatan dengan presentase 24,4\%. 
Tabel 5

Distribusi Frekuensi Responden Berdasarkan Status Kepegawaian di RSUD Mgr. Gabriel Manek, SVD Atambua, 21 Januari - 21 Februari 2015(N: 160)

\begin{tabular}{ccc}
\hline $\begin{array}{c}\text { Variabel } \\
\text { (Status Kepegawian) }\end{array}$ & Frekuensi & Presentase \\
\hline PNS & 37 & \\
Kontrak & 56 & $17,8 \%$ \\
Suka rela & 67 & $32,2 \%$ \\
\hline Total & 160 & $100 \%$ \\
\hline
\end{tabular}

Tabel 5 menunjukkan bahwa dari 160 responden, terdapat 67 orang responden yang bekerja sebagai tenaga sukarela dengan presentase $32,2 \%, 56$ orang responden yang bekerja sebagai tenaga kontrak dengan presentase 26,9\%, dan 37 orang responden lainnya adalah pns dengan presentase $17,8 \%$.

Tabel 6

Motivasi Kerja Perawat di RSUD Mgr. Gabriel Manek. SVD Atambua, 21 Januari - Februari 2015 (N:160)

\begin{tabular}{lcc}
\hline Variabel & Frekuensi & Presentase \\
\hline Motivasi kerja & & \\
Baik & 88 & $55 \%$ \\
Kurang baik & 72 & $45 \%$ \\
\hline Total & 160 & $100 \%$ \\
\hline
\end{tabular}

Tabel 6 menunjukkan bahwa dari 160 responden, terdapat 88 orang responden yang memiliki motivasi kerja yang baik dengan presentase 55\%, dan 72 orang responden lainnya memiliki motivasi kerja kurang baik dengan presentase $45 \%$. 
Tabel 7

Kinerja Perawat di RSUD Mgr. Gabriel Manek, SVD Atambua, 21 Januari 21Februari 2015

$(\mathrm{N}: 160)$

\begin{tabular}{lcc}
\hline Variabel & Frekuensi & Presentase \\
\hline Kinerja Perawat & 52 & $32,5 \%$ \\
Baik & 108 & $67,5 \%$ \\
Kurang baik & 160 & $100 \%$ \\
\hline Total & & \\
\hline
\end{tabular}

Tabel 7 menunjukkan bahwa dari 160 responden, terdapat 108 orang responden yang memiliki kineja yang kurang baik dengan presentase 67,5\%, dan 52 orang responden lainnya memiliki kinerja yang baik dengan presentase $32,5 \%$.

Tabel 8

Hubungan Motivasi Kerja dan Kinerja Perawat

di RSUD Mgr. Gabriel Manek, SVD Atambua, 21 Januari - 21 Februari 2015(N: 160)

\begin{tabular}{|c|c|c|c|c|c|c|c|c|}
\hline \multirow[t]{2}{*}{ Vaiabel } & \multicolumn{4}{|c|}{ Kinerja Perawat } & & & \multirow[t]{2}{*}{ OR $(95 \% \mathrm{CI})$} & \multirow{2}{*}{$\begin{array}{c}\mathrm{P} \\
\text { Value }\end{array}$} \\
\hline & \multicolumn{2}{|c|}{ Baik } & \multicolumn{2}{|c|}{ Kurang Baik } & \multicolumn{2}{|c|}{ Total } & & \\
\hline Motivasi Kerja: & $\mathrm{F}$ & $\%$ & $\mathrm{~F}$ & $\%$ & $\mathrm{~F}$ & $\%$ & & \\
\hline Kurang Baik & 47 & 65.3 & 25 & 34.7 & 72 & 100 & 31.208 (11.201 & $* 0.000$ \\
\hline Baik & 5 & 5.7 & 83 & 94.3 & 88 & 100 & $-86.925)$ & \\
\hline Total & 52 & 32.5 & 108 & 67.5 & 160 & 100 & & \\
\hline
\end{tabular}

* Bermakna pada $\alpha<0,05$

Pada tabel 8, hasil analisa bivariat dengan uji chi square menunjukkan bahwa, terdapat $47(65.3 \%)$ orang perawat yang memiliki motivasi kerja kurang baik namun menunjukkan kinerja yang baik, dan terdapat 83 (94.3\%) orang perawatn yang memiliki motivasi kerja yang baik namun menunjukkan kinerja yang kurang baik. Analisis lebih lanjut ditemukan $\mathrm{p}$ value $=0.000$ artinya terdapat hubungan antara motivasi kerja dengan kinerja perawat di RSUD Mgr. Gabriel Manek, SVD Atambua. Analisis lebih lanjut lagi ditemukan nilai OR nya sebesar 31.208 (95\% CI ; 11.201 - 86.925) yang berarti perawat yang memiliki motivasi kerja yang baik memiliki peluang sebesar 31.208 kali untuk menunjukkan kinerja yang kurang baik. 
Pembahasan

Permasalahan yang di bahas dalam penelitian ini adalah hubungan antara motivasi kerja dengan kinerja perawat di ruang rawat inap RSUD Mgr. Gabriel Manek, SVD Atambua.

Dari hasil analisa univariat diketahui, terdapat 55\% (88 orang) responden memiliki motivasi kerja yang baik dan hasil analisa bivariat terdapat $65,3 \%$ (47 orang) perawat yang memiliki motivasi kerja yang kurang baik namun memiliki kinerja yang baik. Hal ini sejalan dengan penelitian yang dilakukan oleh Nikmatul Fitri tahun 2007 tentang hubungan antara motivasi kerja dengan kinerja perawat di rung rawat inap RSUD Tugurejo Semarang, hasil penelitian di dapatkan bahwa sebagian besar responden memiliki motivasi kerja tinggi yaitu $86,5 \%$ dan sedang $13,5 \%$.

Motivasi Kerja adalah keadaan kejiwaan dan sikap, mental manusia yang memberi tenaga, mengarahkan, menyalurkan, mempertahankan, dan melanjutkan tindakan dan perilaku karyawan atau tenaga kerja (Tansuhaj, et al (1998)).

Sehingga peneliti berpandapat bahwa dari 160 responden terdapat $65,3 \%$ (47 orang) perawat pelaksana di ruang rawat inap RSUD Mgr. Gabriel Manek,SVD Atambua memiliki motivasi kerja yang kurang baik namun memiliki kinerja yang baik. Motivasi kerja kurang baik salah satunya disebabkan karena belum adanya pemberian penghargaan dan kurangnya promosi kenaikkan pangkat dan jabatan kepada petugas yang melakukan tugas dengan baik.

Dari hasil analisa univariat yang telah dilakukan, terdapat $67,5 \%$ (108 orang) perawat yang memiliki kinerja yang kurang baik dan hasil analisa bivariat , terdapat 94,3\% (83 orang) perawat yang memiliki kineja yang kurang baik namun memiliki motivasi kerja yang baik. Hal ini sejalan dengan penelitian yang di lakukan oleh Nikmatul Fitri tahun 2007 tentang hubungan antara motivasi kerja dengan kinerja perawat di rung rawat inap RSUD Tugurejo Semarang, hasil penelitian di dapatkan bahwa 70,3\% responden memiliki kinerja yang tinggi dan sebanyk $29,7 \%$ responden memiliki kinerja sedang.

Kinerja perawat merupakan hasil kerja yang dicapai seseorang dalam melaksanakan tugas-tugas yang dibebankan kepadanya didasarkan 
atas kecakapan, pengalaman, kesungguhan dan waktu (Kinman et al, (2001)).

Peneliti berpendapat bahwa dari 160 responden, terdapat $94,3 \%$ (83 orang) perawat pelaksana di ruang rawat inap RSUD Mgr. Gabriel Manek, SVD Atambua memiliki kinerja yang kurang baik namun memiliki motivasi kerja yang baik. Kinerja perawat yang kurang baik disebabkan karena kurangnya motivasi atau dorongan dari atasan dan diri sendiri.

Hasil analisa bivariat dengan uji chi square di dapatkan bahwa sebagian besar responden memiliki motivasi kerja yang baik namun menunjukkan kinerja yang kurang baik sebesar 94,3\% (83 orang), dan terdapat $65,3 \%$ (47orang) perawat yang memiliki motivasi kerja kurang baik namun menunjukkan kinerja yang baik. Analisa lebih lanjut di dapatkan sig value atau $p$ value 0,000 yang artinya terdapat signifikan antara motivasi kerja dengan kinerja perawat di RSUD Mgr. Gabriel Manek, SVD Atambua. Analisa lebih lanjut lagi di temukan nilai OR nya sebesar $31.208(95 \%$ CI ; 11,201 86.925) yang berarti perawat yag memiliki motivasi kerja yang baik memiliki peluang sebesar 31.208 kali untuk menunjukkan kinerja yang kurang baik. Peneliti berpendapat bahwa dari hasil penelitian terdapat 94,3\%(83 orang) perawat pelaksana yang memiliki motivasi kerja baik namun menunjukkan kinerja yang kurang baik, sehingga perlu adanya penelitian yang lebih lanjut mengenai hubungan motivasi kerja dengan kinerja perawat di ruang rawat inap RSUD Mgr. Gabriel Manek, SVD Atambua. Hal ini sejalan dengan penelitian yang dilakukan oleh Nikmatul Fitri tahun 2007 dengan judul Hubungan Motivasi Kerja dengan Kinerja Perawat di Ruang Rawat Inap RSUD Tugurejo Semarang, hasil penelitian di dapatkan bahwa sebagian besar responden memiliki motivasi kerja tinggi yaitu $86,5 \%$ dan sedang 13,5\%. Hasil kinerja menunjukkan bahwa $70,3 \%$ responden memiliki kinerja yang tinggi dan sebanyk 29,7\% responden memiliki kinerja sedang. 


\section{Kesimpulan}

Hasil penelitian ditemukan 88 orang responden yang memiliki motivasi kerja yang baik dengan presentase $55 \%$, dan 72 orang responden lainnya memiliki motivasi kerja kurang baik dengan presentase 45\%. Dari 160 responden, terdapat 108 orang responden yang memiliki kineja yang kurang baik dengan presentase $67,5 \%$, dan 52 orang responden lainnya memiliki kinerja yang baik dengan presentase $32,5 \%$. Sebagian besar responden memiliki motivasi kerja yang baik namun menunjukkan kinerja yang kurang baik sebesar 94,3\% (83 orang), dan terdapat $65,3 \%$ (47orang) perawat yang memiliki motivasi kerja kurang baik namun menunjukkan kinerja yang baik. Analisa lebih lanjut di dapatkan sig value atau $\mathrm{p}$ value untuk hubungan yang signifikan antara hubungan motivasi kerja dan kinerja perawat sebesar 0,000 artinya terdapat hubungan antara motivasi kerja dengan kinerja perawat di RSUD Mgr. Gabriel Manek, SVD Atambua. Analisa lebih lanjut lagi di temukan nilai OR nya sebesar 31.208 (95\% CI; 11,201
- 86.925) yang berarti perawat yag memiliki motivasi kerja yang baik memiliki peluang sebesar 31.208 kali untuk menunjukkan kinerja yang kurang baik.

\section{Referensi}

Ali. ( 2001). Perawat Sebagai Pemberi Asuhan Keperawatan, Jakarta: EGC

Amabile et al. (1994). Salesperson Motivation to Perform and Job Satisfaction: A Sales Contest Participant Perspective," Journal of Personal Selling\& Sales Management.

Amstrong, Michael. (1994). "Handbook of Personal Management Practise", 4th Edition, Kopan Page Ltd., London Anugrahini. (2014). Pedomam Teknik Penyusunan Karyan Tulis Ilmia Diplom III Keperawatan.

Asmadi. (2008). Konsep Ilmu Keperawatan, Jakarta: Salemba Medika.

Cooke. (1999). Control And Motivation In Sales Management through The Compensation Plan, Journal Of Marketing Theory and $P$ ratices. 
Dayle P. And Wong. (1998).

Nursalam. (2011). Proses dan Marketing and Competitive Dokumentasi Keperawatan, Performance; An Empirical Study.

Jakarta; Salemba Medika.

Dessler. (1992). Management Sumber Daya Manusia,

Fuad Mas'ud. (2004). Survai Diagnosis Organisasional, Badan Penerbit Universitas Diponegoro, Semarang

Grant, Ken et al. (2001). The Role of Satisfaction With Territory Design on The Motivation, Attitudes, and Work Outcomes of Salespeople, Journal of The Academy of Marketing Sciences.

Kinman et al. (2001). The Role of

Motivation to Learn in Management Education, Journal of Workplace Learning.

Robbins. Stephen P. (1996). Organizational Behavior Concept, Controversiest, Application, Eaglewoods Cliffs, Prentice Hall Inc.

Tansuhaj. (1998). A Service Marketing Management Model: Integrating Internal and External Marketing Function, The Journal of Service Marketing.

Vest M. J., Scott K.D., and Markham S.E. (1994). Self Rated Performance and Pay Satisfaction, Merit Increase Satisfaction and Instrumentally Beliefs In A Merit Pay Environment, Journal of Business and Psychology.

Luthans, Fred. (1995).

Organizational Behavior, Seventh

Edition, Boston.

McNeese -Smith, Donna. (1996). Increasing Employee Productivity, Job Satisfaction, and Organizational Commitment Hospital \& Health Services Administration.

Notoatmodjo. (2002). Ilmu Perilaku Kesehata, Jakarta : Rineka Cipta 